\title{
Cost of Production for Processed Oranges in Southwest Florida, 2016/17
}

\author{
Ariel Singerman ${ }^{2}$
}

\section{Introduction}

This article summarizes the cost of production per acre for processed oranges grown in southwest Florida during the 2016/17 season. Typical users of the estimates presented herein include growers and consultants, who use them as a benchmark; property appraisers, who use them to compute the taxes for property owners; and researchers, who use the estimates to evaluate the economic feasibility of potential new technologies.

\section{Production Cost}

A total of seven growers participated in the data collection process by attending the meeting that took place at the UF/ IFAS Extension office in LaBelle in May 2017. On the day of the meeting, growers brought a completed survey form that had been distributed to them beforehand. The questionnaire asked growers to provide annual, per-acre costs by program for a "typical" irrigated, mature grove (10+ years old), including costs related to their tree replacement programs.

During the meeting, each grower used a "clicker" or remote device to enter the costs for each caretaking program. Using clickers to collect the data kept the process anonymous and confidential. Surveying a panel of growers to obtain the costs of their production programs allows us to report estimates that closely reflect growers' cost. This is particularly important because, since the outbreak of HLB, growers have been modifying their practices from year to year in an attempt to cope with the disease. The cost estimates below

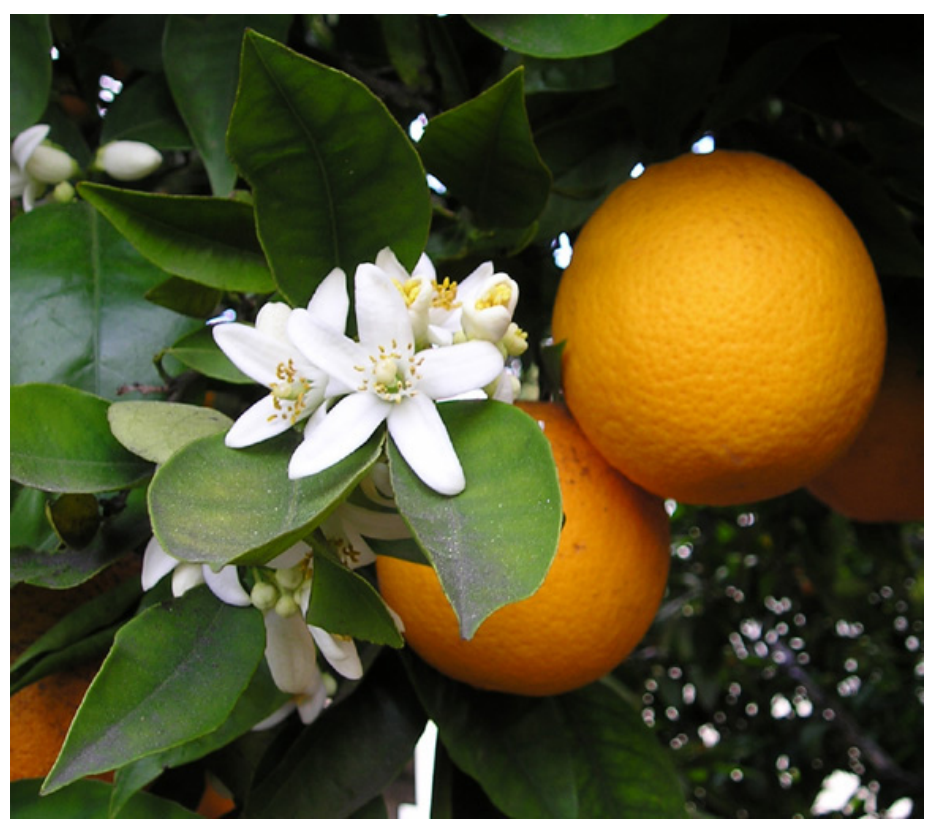

Credit:. USDA

do not represent any individual operation. Instead, their purpose is to serve as a benchmark for the Florida citrus industry.

The figures below were obtained by computing the weighted average of the responses by the acreage of each of the participating growers. Their combined operations account for approximately 36,400 acres. The latest acreage for oranges in southwest Florida was estimated at 257,298 (USDA-NASS 2016). Thus, the sample of growers represented $14 \%$ of the acreage devoted to oranges in that region.

1. This document is FE1038, a publication of the Food and Resource Economics Department, UF/IFAS Extension. Published February 2018. Visit the EDIS website at http://edis.ifas.ufl.edu.

2. Ariel Singerman, assistant professor, Food and Resource Economics Department, UF/IFAS Citrus Research and Education Center, Lake Alfred, FL.

The Institute of Food and Agricultural Sciences (IFAS) is an Equal Opportunity Institution authorized to provide research, educational information and other services

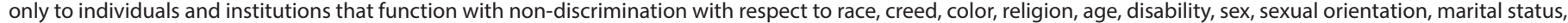

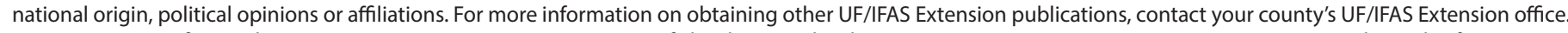
U.S. Department of Agriculture, UF/IFAS Extension Service, University of Florida, IFAS, Florida A \& M University Cooperative Extension Program, and Boards of County Commissioners Cooperating. Nick T. Place, dean for UF/IFAS Extension. 
The main change in 2016/17 compared to previous seasons was that streptomycin and oxytetracycline were allowed to be used in Florida's citrus groves in March 2016 in an attempt to manage HLB. The basic tenet for their use is not to eliminate the bacteria (Candidatus Liberibacter asiaticus) within HLB-affected trees, but to reduce its titer (i.e., presence and amount within the tree). The reduction in titer is expected to improve the trees' condition, which, in turn would make them more productive.

Table 1 shows the cultural costs of production by program. The estimates include both the costs of materials and the costs associated with their application. The total cost for weed management, which includes chemical and mechanical mowing as well as herbicides, was $\$ 241.77$ per acre. At $\$ 658.93$ per acre, foliar sprays represented the largest production cost. Fertilizer was the second largest expense at $\$ 412.69$ per acre. Citrus Health Management Areas (CHMA) sprays accounted for $\$ 68.35$ per acre. The expense for pruning was $\$ 31.64$ per acre, while that for irrigation was $\$ 208.88$ per acre. Adding all the costs listed above, the cultural cost of growing oranges for processing during 2016/17 without tree replacement was \$1,622.27 per acre.

Growers were also asked to provide details regarding their reset practices, including the number of trees replaced in their groves. On average, growers replaced seven trees per acre during 2016/17. The total cost of tree replacement, including tree removal, site preparation, and supplemental care of those seven young trees was estimated at $\$ 321.83$ per acre. Adding that figure to the total cost above yields a total production cost with tree replacement of $\$ 1,944.09$ per acre.

Figure 1 depicts a double pie chart. The larger pie shows the cost of each program as well as the percentage relative to the total cultural production costs with tree replacement. The smaller pie in Figure 1 provides greater detail regarding the individual components included in the foliar sprays for a total of $\$ 658.93$ per acre. Insecticides accounted for $\$ 207.04$ per acre, representing $11 \%$ of the cultural cost of production; fungicides accounted for $\$ 56.17$ per acre (3\%); foliar nutritionals for $\$ 146.08$ per acre (7\%); aerial application totaled $\$ 40.57$ per acre (2\%); and ground application of materials was $\$ 114.96$ per acre $(6 \%)$.

Figure 2 shows a comparison of the cost of the main production programs in $2016 / 17$ relative to $2015 / 16$. The figure shows that weed management increased by $\$ 32$ per acre. Part of that increase was due to growers mowing some of the brush left behind after pruning, whereas the pruning program itself showed a decrease of $\$ 18$ per acre compared to the previous season. Foliar sprays increased by $\$ 47$ per acre, which was driven by the introduction of bactericide use. Fertilizer decreased by $\$ 41$ per acre. The increase in irrigation by $\$ 28$ per acre was mostly driven by an increase in fuel use due to a drier spring. The cost of tree replacement decreased by $\$ 64$ because growers replaced, on average, seven trees per acre per year instead of nine as in 2015/16.

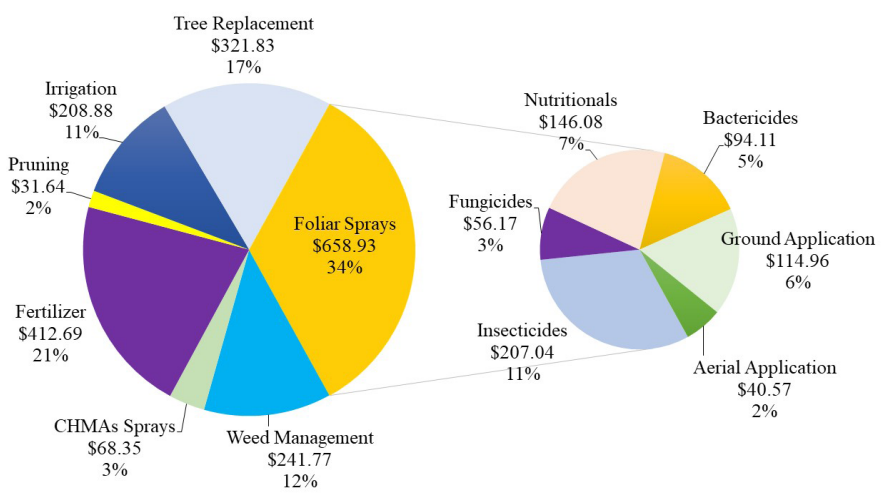

Figure 1. Cultural costs of production (in dollars per acre) for processed oranges grown in southwest Florida, 2016/17

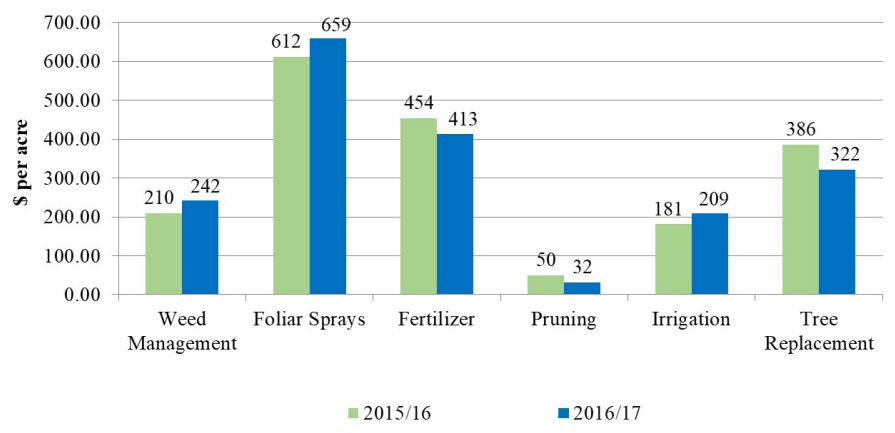

Figure 2. Cost of production by program for processed oranges grown in southwest Florida, 2015/16 vs. 2016/17

In addition to cultural costs, growers typically have to incur other costs when managing their groves; these other costs include management, regulatory, and opportunity costs. Table 2 shows the total cost of production for processed oranges grown in southwest Florida during 2016/17 was $\$ 2,376.31$ per acre. Based on this estimate, the break-even prices per box and per pound solids for different levels of yield are presented in Table 3. Break-even prices were calculated on an on-tree and delivered-in basis. The latter assumes harvesting costs per box were $\$ 3.16$, which is based on the results of the survey "Picking, Roadsiding, and Hauling Charges for Florida Citrus, 2016/17” (Singerman et al. 2017). The calculations in Table 3 also include the Florida Department of Citrus (FDOC) assessment of $\$ 0.07$ per box for the 2016/17 season. Thus, for example, the on-tree and delivered-in break-even prices for covering the total costs of production with yield at 200 boxes per acre were $\$ 2.00$ and $\$ 2.54$ per pound solids, respectively. 


\section{Summary}

This article presents a summary of the $2016 / 17$ costs of production for processed oranges grown in southwest Florida. The methodology chosen to collect the data consisted of surveying growers directly to closely reflect growers' costs in the era of HLB. The main change this season was the introduction of bactericides use by growers to attempt to reduce the titer (i.e.: presence and amount) of the bacteria (Candidatus Liberibacter asiaticus) within HLB-affected trees. The total cost of production for processed oranges in $2016 / 17$ was $\$ 2,376.31$ per acre.

\section{References}

Singerman, A., M. Burani-Arouca, S. H. Futch, R. Ranieri. 2017. Harvesting Charges for Florida Citrus, 2016/17. UF/ IFAS Citrus Research and Education Center, Lake Alfred, FL. http://www.crec.ifas.ufl.edu/extension/economics/ harvesting_charges.shtml

USDA-NASS. 2016. Commercial Citrus Inventory: Preliminary Report. Maitland, FL: USDA-NASS, Florida Department of Agricultural Services. 
Table 1. Cultural costs of production per acre for processed oranges in southwest Florida, 2016/17

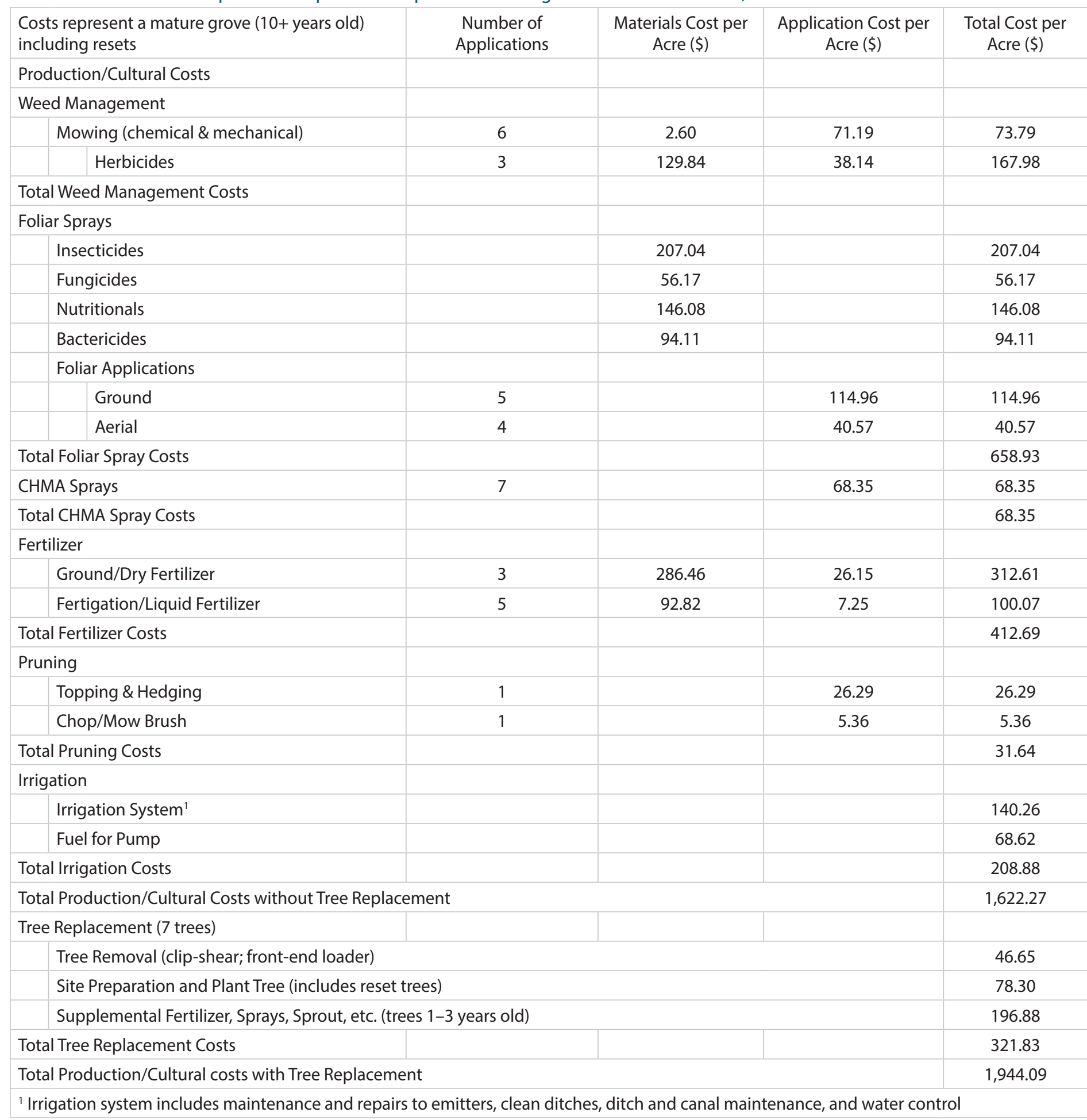


Table 2. Total costs of production per acre for processed oranges in southwest Florida, 2016/17

\begin{tabular}{|c|c|}
\hline Variable & Total Cost per Acre (\$) \\
\hline Total Cultural Cost of Production & $1,944.09$ \\
\hline \multicolumn{2}{|l|}{ Other Costs } \\
\hline Interest on Operating (Cultural) Costs & 97.20 \\
\hline Management Cost & 122.31 \\
\hline Property Tax/Water Management Tax & 28.73 \\
\hline Interest on Average Capital Investment & 183.98 \\
\hline Total Other Costs & 432.22 \\
\hline Total Grower Costs & $2,376.31$ \\
\hline
\end{tabular}

Table 3. Breakeven price per box and per pound solids for processed oranges in southwest Florida, 2016/17

\begin{tabular}{|l|c|c|c|c|c|c|c|c|c|c|}
\hline & \multicolumn{7}{c|}{ Yield (boxes per acre) } \\
\hline & 175 & 200 & 225 & 250 & 275 & 300 & 325 & 350 & 375 \\
\hline & \multicolumn{7}{|c|}{ Dollars per Acre } \\
\hline Cost of Production & 2,376 & 2,376 & 2,376 & 2,376 & 2,376 & 2,376 & 2,376 & 2,376 & 2,376 \\
\hline Pick and Haul & 553 & 632 & 711 & 790 & 869 & 948 & 1,027 & 1,106 & 1,185 \\
\hline FDOC Assessment & 12 & 14 & 16 & 18 & 19 & 21 & 23 & 25 & 26 \\
\hline Total Delivered-in Cost & 2,942 & 3,022 & 3,103 & 3,184 & 3,265 & 3,345 & 3,426 & 3,507 & 3,588 \\
\hline & & & & & & & \\
\hline
\end{tabular}

